\title{
The influence of drainage boundaries on specific mass-balance results: a case study of Engabreen, Norway
}

\author{
Hallgeir ELVEHØY, Miriam JACKSON, Liss M. ANDREASSEN
}

\author{
Norwegian Water Resources and Energy Directorate (NVE), Middelthunsgate 29, PO Box 5091, Majorstua, \\ NO-0301 Oslo, Norway \\ E-mail: hae@nve.no
}

\begin{abstract}
Mass-balance measurements were initiated on Engabreen, an outlet glacier from the Svartisen ice cap, Norway, in 1970. The glacier boundary was defined based on where meltwater drained, as the interest in Engabreen was mainly hydrological. However, the apparent discrepancy between the calculated cumulative glacier mass balance since 1970 and changes in glacier geometry prompted a re-examination of the glacier boundary. The glaciological drainage boundary is defined by studying whether ice flow physically contributes to Engabreen tongue and corresponds to a glacier with an area of $27.2 \mathbf{~ k m}^{2}$, significantly smaller than that defined by the hydrological drainage boundary at $39.6 \mathrm{~km}^{2}$. This glaciological drainage boundary is here named the ice-flow perimeter. The area difference between this and the hydrological drainage boundary is largest for the altitudinal range 1300$1400 \mathrm{~m}$ a.s.l. Generally, the 'glaciological' glacier is lower in mean altitude than the 'hydrological' glacier, and this affects the calculated specific mass balance. Using the glaciological boundary leads to reductions in mean annual winter and summer balance (when spatial differences are ignored) of $0.12 \mathrm{~m}$ w.e. (from 2.92 to $2.80 \mathrm{~m}$ w.e.) and $0.15 \mathrm{~m}$ w.e. (from -2.32 to $-2.47 \mathrm{~m}$ w.e.), respectively. The reduction in mean net balance for the period $1970-2006$ is $0.27 \mathrm{~m}$ w.e. (from +0.59 to $+0.32 \mathrm{~m}$ w.e.) which is about $50 \%$ of the calculated mass surplus in this period. This illustrates that the choice of glacier outline can significantly influence the long-term cumulative mass balance and that results from outlet glaciers must be interpreted with care when used for regional estimates of glacier change.
\end{abstract}

\section{INTRODUCTION}

Glacier mass-balance data are used to estimate the contribution to sea-level change from melting glaciers (e.g. Zuo and Oerlemans, 1997; Dyurgerov and Carter, 2004; Oerlemans and others, 2005; Raper and Braithwaite, 2006). Glaciers are also sensitive indicators of climate 140change, and the cumulative mass-balance curves are used to report on the development of glaciers in different regions (e.g. Lemke and others, 2007; WGMS, 2007). The estimates of glacier change and sea-level rise depend heavily on the quality of measurements and calculations for the few glaciers where there exists a long-term series of mass-balance data. Glacier mass balance is monitored using the direct glaciological method whereby the measurements are extrapolated from point observations to the surface area of the glacier or glacier basin. The long-term cumulative net balance is sensitive to systematic errors which accumulate, and thus influence the accuracy of estimates of glacier changes and sea-level rise.

Mass-balance measurements in Norway have traditionally been related to the needs of hydropower development. The primary interest was the effect of glaciers on run-off in hydrological catchments. Hence, glacier boundaries were often defined by catchments of downstream gauging stations. Where the glacier bottom topography is known, the hydrological drainage divides can be mapped by calculating the hydraulic head. The glaciological drainage divide, or ice-flow perimeter, defines the area draining ice to glacier outlets and can deviate considerably from the hydrological drainage divide, as illustrated in previous studies of Blåmannsisen (Kennett, 1990) and western Svartisen (Kennett and others, 1997). In Norway, 28 of the
42 glaciers where mass balance has been measured are outlets from plateau glaciers. In 2007, 10 out of 13 measured glaciers were outlet glaciers (Kjøllmoen, 2008).

Engabreen is an outlet glacier from western Svartisen ice cap, northern Norway. Mass-balance measurements were initiated on the glacier in 1970 in association with a planned hydropower scheme in the area. The glacier has the only long term mass-balance series in northern Norway, and the series has been used in several studies (e.g. Engeset and others, 2000; Rasmussen and Conway, 2005; Schuler and others, 2005). Engabreen is also one of 30 reference glaciers with long-term uninterrupted measurements used by the World Glacier Monitoring Service (WGMS) for calculating mean specific balances (WGMS, 2007).

Here we investigate the influence on area-averaged massbalance results from three different glacier boundaries for Engabreen: ice drainage to a hydrological gauging station based on surface topography; subglacial water drainage to a hydrological gauging station based on glacier bed topography and ice thickness; and ice drainage to the glacier tongue based on ice movement and surface topography. The objectives are to study the impact of different drainage divides on the area-to-altitude distribution and the implications on the long-term mass-balance record.

\section{SETTING}

Engabreen $\left(66^{\circ} 40^{\prime} \mathrm{N}, 13^{\circ} 50^{\prime} \mathrm{E}\right)$ is a northern outlet glacier from the western Svartisen ice cap $\left(221 \mathrm{~km}^{2}\right)$ in Nordland, northern Norway. It is located in a mountainous area close to the ocean, with peaks at 1400-1600 m a.s.I. Engabreen covers about $39 \mathrm{~km}^{2}$ (depending on how the boundaries are defined) and ranges in altitude from 10 ma.s.l. (in 2001) to 


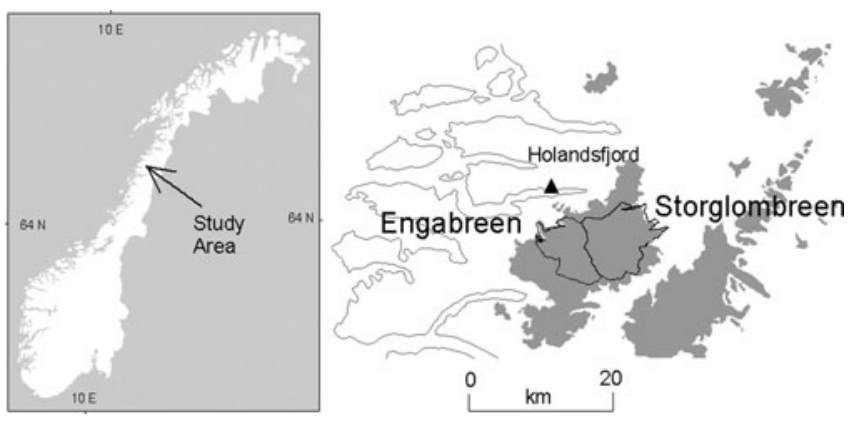

Fig. 1. Location map of Engabreen and Storglombreen, the major outlets from western Svartisen. Glacier areas are light grey. The global positioning system base Holandsfjord is shown (triangle).

1575 ma.s.l. (Figs 1 and 2). Below 900 ma.s.l., there is a heavily crevassed icefall which accounts for $7 \%$ of the glacier area. The glacier tongue is exposed to periodic melting throughout the winter due to the frequent occurrence of positive temperatures at sea level in a maritime climate. The distance along a flowline from the ice divide west of Snøtind to the glacier terminus is $11 \mathrm{~km}$. The average slope on the plateau above $900 \mathrm{~m}$ a.s.l. is $4^{\circ}$, while the mean slope of the icefall is $15^{\circ}$.

\section{DATA}

\section{Mass-balance data}

Glacier mass-balance observations at Engabreen began in 1970. The mass-balance data are published annually or biannually in the Norwegian Water Resources and Energy Directorate (NVE) report series (e.g. Kjøllmoen, 2008). The data from Engabreen are also reported to the WGMS and published in its Glacier Mass Balance Bulletin series (e.g. WGMS, 2007).

The mass balance is measured by the direct glaciological method (Østrem and Brugman, 1991). The extent of the measurements has varied considerably over time. A total of 20-30 stake locations were used between 1970 and 1982, and snow depth was sounded at 200-400 points on the glacier plateau. Snow density was measured at one to three locations. Mass balance is presently measured at five to ten stake locations, snow depth is measured at approximately 50 points, and the snow density is measured at one location. The mass balance is calculated using a stratigraphic method, i.e. between two successive 'summer surfaces' (surface minima). Between 1970 and 1988 the mass balance was calculated using the balance-map method, while the balance vs altitude method has been used since 1989. The mass-balance methods and calculations are described in further detail by Andreassen and others (2005) and Kjøllmoen (2008). Average specific winter and summer mass balance are 2.92 and $-2.32 \mathrm{mw}$.e. The assumed uncertainty in annual specific net balance is $\pm 0.3 \mathrm{~m}$ w.e., and the corresponding uncertainty for 37 years of cumulative net balance is $\pm 2 \mathrm{~m}$ w.e. (Andreassen and others, 2002, 2005).

\section{Digital elevation models}

Several digital elevation models (DEMs) exist for Engabreen. The oldest is based on a map constructed from aerial photography on 24 August 1968. The mass-balance calculations for Engabreen were made using this map until 2003. Four high-quality DEMs were constructed from laser scanning measurements in the period 2001-03, and their vertical accuracy is better than $0.3 \mathrm{~m}$ (Geist and others, 2005). The DEM from 24 September 2001 has been used for mass-balance calculations since 2004. The glacier margin was drawn manually from terrain shape in this DEM, as the glacier outline is better defined in September due to less snow at the glacier margin, but this DEM was incomplete at the glacier tongue. Hence, a DEM from 30 June 2003 is used to calculate the altitudinal distributions.

\section{Bed topography}

Bed topography on western Svartisen has been mapped using ground-penetrating radar (GPR) from the glacier surface (Sætrang, 1988). In addition, ice thickness has been measured in the icefall of Engabreen using helicopter-borne GPR (Kennett and others, 1993). A DEM of the bed topography of western Svartisen was then calculated from interpolated ice thickness and surface topography (Kennett and others, 1997).

\section{Drainage divides}

Mass-balance measurements at Engabreen were initiated with the primary purpose of investigating the influence of glaciers on regional hydrology for hydroelectric power planning. The investigated area included all glaciers in the catchment to lake Engabrevatnet where river discharge was measured, i.e. the two outlet glaciers Engabreen and Litlebreen, and large areas on the plateau of Svartisen. Without knowledge of the ice thickness or ice dynamics, the catchment boundary on the glacier plateau was drawn based on the surface topography from 1968, thereby corresponding to an ice divide defined only by terrain slope (Tvede and others, 1971). In the southeast basin close to Snøtind, the divide was drawn parallel to the general surface slope in the middle of the basin where the glacier is $>400 \mathrm{~m}$ thick. This ice drainage divide is shown in Figure 2.

When glacier run-off is assessed, a hydrological drainage basin must be used. Glacier meltwater percolates through the glacier and flows along the glacier bed driven by gradients in hydraulic potential elevation. Based on glacier bottom topography and ice thickness, the hydraulic head or hydraulic potential elevation at Svartisen was mapped and the drainage boundary to Engabrevatnet was defined (Kennett and others, 1997). The boundaries based on surface topography and hydraulic potential elevations are quite similar, except in the southeast basin where the hydraulic potential elevation boundary includes most of this basin (Fig. 2).

\section{METHODS}

\section{Velocity measurements}

Previous studies of surface dynamics in the southeastern part of Engabreen (e.g. Jackson and others, 2005) have suggested that ice flow here may be towards the east rather than the west, and hence the ice actually belongs glaciologically to the glacier Storglombreen. To study this further, nine stakes were installed in the region of the boundary between Engabreen and Storglombreen in summer 2006 (Fig. 1). Stakes were about $500 \mathrm{~m}$ apart and were thus all situated within an area of $1 \mathrm{~km}^{2}$. 
Displacement was measured using the differential global positioning system (dGPS) over a 98 day period in order to determine the direction of ice flow. Measurements were made on 28 June, 3 August and 4 October. The base station for the GPS measurements in August and October was at Holandsfjord (Fig. 1). The station at Holandsfjord is part of the geodetic network of the Norwegian Mapping Authority, and has an absolute accuracy of $3 \mathrm{~cm}$ horizontally and $5 \mathrm{~cm}$ vertically. Holandsfjord is within $11 \mathrm{~km}$ of the stakes, so the absolute accuracy of positions calculated using Holandsfjord is $5 \mathrm{~cm}$. As the same base station was used for August and October, the displacement and angle measured over this period depend only on the relative accuracy, which is better than $2 \mathrm{~cm}$. For the measurements in June, some of the stake positions were calculated using a base station at Bautaen (Fig. 2) and others using the SATREF station at Bodø (SATREF is a satellite-based reference system of the Norwegian Mapping Authority and provides correction data for GPS measurements made without a base station). Bautaen is within $4 \mathrm{~km}$ of the stakes, so the absolute accuracy of positions is within $11 \mathrm{~cm}$. Positions calculated using the SATREF station at Bodø at a distance of about $73 \mathrm{~km}$ have an accuracy within $10 \mathrm{~cm}$. Both speed and direction of surface movement were approximately consistent for each measurement period (Table 1).

On the whole, the GPS measurements were made over a long enough period, in terms both of the amount of time the receiver collected satellite data and of the time between position measurements, that the velocity data given are assumed to be reliable in determining the direction of ice flow as well as approximate magnitude. Some of the stakes measured in October were either slanted or had melted out, but their position was still easily distinguishable. This will have incorporated an additional uncertainty into the October positions, but not more than $10 \mathrm{~cm}$, and the magnitude of errors is small compared with displacements.

\section{Altitudinal area distribution}

We made three glacier basins from the three different drainage divides and the glacier outline from 24 September 2001. The DEM ( $5 \mathrm{~m}$ cell size) from 30 June 2003 was then cut with the glacier basins, and the area-elevation distribution was calculated within $100 \mathrm{~m}$ elevation bins. The

Table 1. Stake velocity measurements on Engabreen in 2006, used to define the ice drainage divide between Engabreen and Storglombreen (Fig. 1). Directions are relative to north $(=0)$, positive towards west, negative towards east. There are missing values where stakes were either melted out or not measured

\begin{tabular}{|c|c|c|c|c|c|c|}
\hline \multirow[b]{2}{*}{ Stake } & \multicolumn{2}{|c|}{28 June-3 Aug. } & \multicolumn{2}{|c|}{3 Aug. -4 Oct. } & \multicolumn{2}{|c|}{28 June-4 Oct. } \\
\hline & $\mathrm{ma}^{-1}$ & $\circ$ & $\mathrm{ma}^{-1}$ & $\circ$ & $\mathrm{ma}^{-1}$ & $\circ$ \\
\hline Northwest & 23 & 17 & & & & \\
\hline North & 32 & -9 & 22 & 2 & 25 & -3 \\
\hline Northeast & 44 & -20 & 22 & -30 & 30 & -24 \\
\hline West & 25 & 14 & 25 & 5 & 25 & 8 \\
\hline Middle & 27 & -3 & & & & \\
\hline East & 24 & -32 & 22 & -30 & 23 & -31 \\
\hline Southwest & 25 & -17 & 25 & 0 & 25 & -6 \\
\hline South & 21 & -8 & 27 & -6 & 25 & -6 \\
\hline Southeast & 17 & -4 & 20 & -20 & 19 & -15 \\
\hline
\end{tabular}

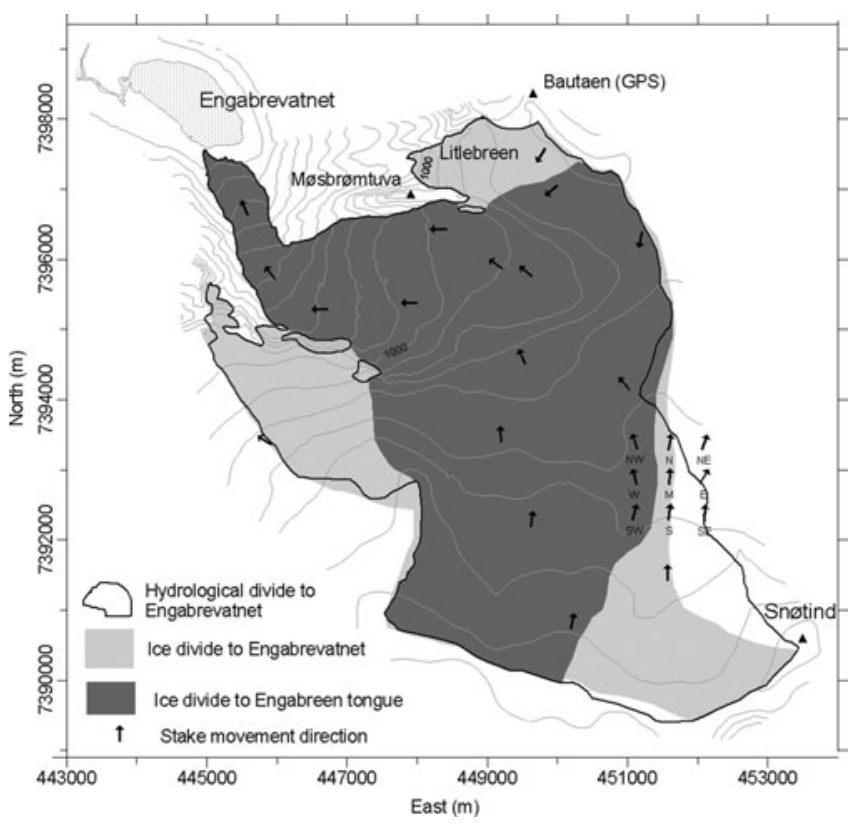

Fig. 2. Three different drainage basins for Engabreen: ice drainage divide based on surface topography (light grey); hydrological drainage divide (black line); and ice drainage based on measured ice movement and surface topography (dark grey). Arrows with letters show direction of movement from velocity measurements from 2006 listed in Table 1.

grid-node counting included all cells where the node point was within the polygon. Gridcells partially inside the poly line but with node point outside the poly line were not included, and gridcells partially inside the poly line with node point inside the poly line were counted as if the entire cell was inside the poly line. Hence the local errors mostly cancelled out.

The uncertainty in point elevations in the DEM is $\pm 0.3 \mathrm{~m}$ (Geist and others, 2005). If the node elevations were linearly distributed with respect to elevation, the uncertainty in area in $100 \mathrm{~m}$ elevation bands would be $\pm 0.4 \%$.

\section{RESULTS}

\section{Ice flow in the southeast basin}

The measured stake displacements range from 5 to $8 \mathrm{~m}$, and are equivalent to an annual speed of $19-30 \mathrm{~m} \mathrm{a}^{-1}$ (Table 1). Two of the stakes were not measured in October, and most of the stakes were tilted due to melting. Hence, the October measurements are probably less accurate than the August measurements (which used the same base station) because it is not entirely certain that the correct position was measured for each stake. However, the original stake position was clear in each case, and this has a minor effect on the results. The three easternmost stakes, and to a lesser extent the three middle stakes, all show a definite component of flow eastwards. The displacement measurements show that ice flow at this part of the hydrological drainage boundary is from west to east; that is, ice that was previously considered to be part of Engabreen actually flows east to Storglombreen. This also agrees with the direction of ice flow shown by interferometric synthetic aperture radar (InSAR) measurements of Svartisen from 1996 (T. Strozzi and others, http:// dib.joanneum.at/integral/results.html, Deliverable No. 8). 


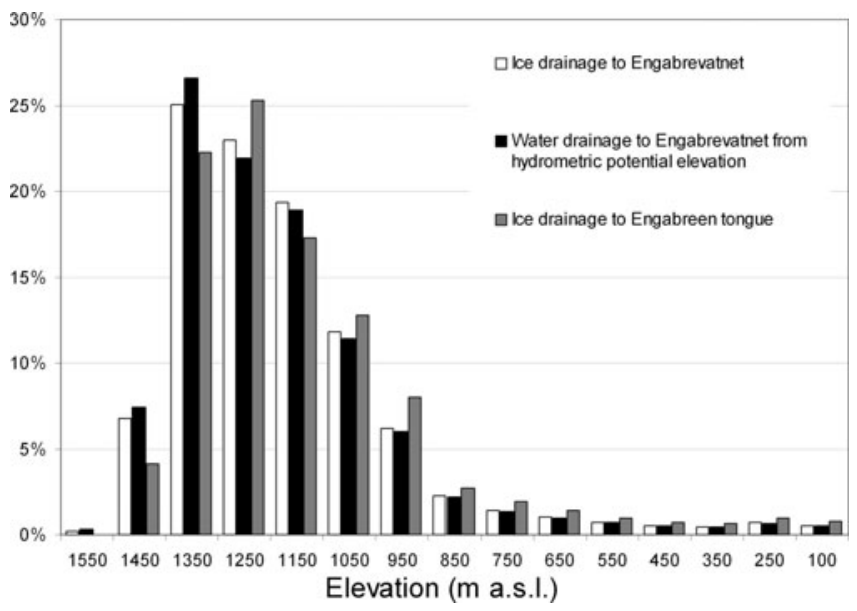

Fig. 3. Area-altitude distributions (in $100 \mathrm{~m}$ elevation bins) from three different drainage divides (Fig. 2) and a DEM from 30 June 2003.

\section{The glaciological drainage basin}

There are three areas where there is thought to be a large discrepancy between ice drainage to the tongue of Engabreen and ice or water drainage to the lake Engabrevatnet.

1. The southeast basin. In the southeast basin close to Snøtind the ice and water flux may contribute to either Engabreen or Storglombreen. Based on the nine stake velocities and the DEM from 30 June 2003, a drainage divide in the southeast basin between ice draining towards Engabreen and Storglombreen, respectively, was defined. The new drainage divide is drawn manually based on stake displacement directions. It is extrapolated further uphill based on the DEM from 30 June 2003. This area covers approximately $4.5 \mathrm{~km}^{2}$ above $1250 \mathrm{~m}$ a.s.I.

2. Litlebreen. The small outlet glacier Litlebreen (Fig. 2), the northeastern part of the glacier area within the catchment to Engabrevatnet, does not contribute ice to the terminus of Engabreen. This area is $1.7 \mathrm{~km}^{2}$ and lies between 870 and $1205 \mathrm{~m}$ a.s.l. The drainage divide between Engabreen and Litlebreen was drawn normal to the contour lines from the eastern end of the peak Møsbrømtuva.

3. The southwestern area. The southwestern part of the catchment to Engabrevatnet is partly separated from the glacier tongue by a cliff band. Some avalanching onto the main glacier occurs, but the contribution of ice seems small. The drainage divide is drawn from the uppermost rock outcrop on the western side, uphill normal to the contour lines. This area covers $3.8 \mathrm{~km}^{2}$

Table 2. Mean specific balances for Engabreen in m w.e. for 19702006

\begin{tabular}{lccc} 
Balance & $\begin{array}{c}\text { Water drainage to } \\
\text { Engabrevatnet } \\
\left(39.6 \mathrm{~km}^{2}\right)\end{array}$ & $\begin{array}{c}\text { Ice drainage to } \\
\text { Engabrevatnet } \\
\left(38.0 \mathrm{~km}^{2}\right)\end{array}$ & $\begin{array}{c}\text { Ice drainage to } \\
\text { Engabreen tongue } \\
\left(27.2 \mathrm{~km}^{2}\right)\end{array}$ \\
\hline Winter & 2.92 & 2.92 & 2.80 \\
Summer & -2.32 & -2.34 & -2.47 \\
Net & 0.59 & 0.58 & 0.32 \\
\hline
\end{tabular}

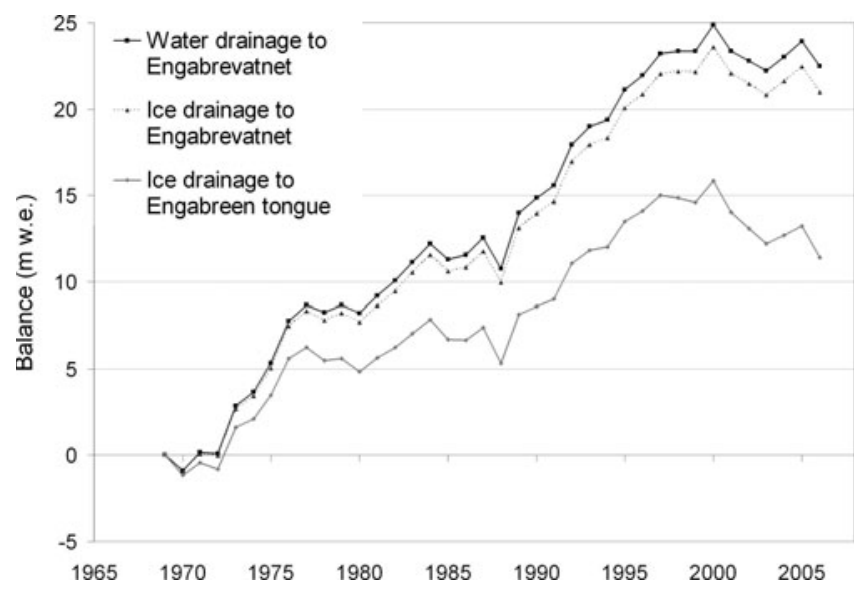

Fig. 4. Cumulative net mass balance at Engabreen, 1970-2006, calculated from annual altitudinal net mass-balance curves and altitudinal area distribution curves from three different glacier drainage divides.

between 950 and $1360 \mathrm{~m}$ a.s.l. The exact location of this boundary is somewhat subjective, but there is an area of at least a few $\mathrm{km}^{2}$ that contributes water to Engabrevatnet but only small ice volumes to the glacier tongue.

The area defined by ice drainage to the tongue of Engabreen $\left(27.2 \mathrm{~km}^{2}\right)$ is considerably smaller than the two areas defined by drainage to Engabrevatnet $\left(38.0\right.$ and $39.6 \mathrm{~km}^{2}$ ). The drainage area defined by ice flow to Engabreen does not include areas around Snøtind (1594 ma.s.l.), the highest peak on Vestisen. Consequently, the maximum elevation of this drainage area is more than $100 \mathrm{~m}$ lower than the other two drainage areas.

\section{Altitudinal area distribution}

The altitudinal area distributions (in \%) for $100 \mathrm{~m}$ elevation bands reveal that the ice drainage basin to Engabreen has a considerably smaller portion of its area between 1300 and $1500 \mathrm{~m}$ a.s.I. than the other two drainage areas, and has a larger portion of its area below 1100 ma.s.l. (Fig. 3). Generally, the glacier area draining ice to the tongue of Engabreen is topographically lower than the glacier area draining water to Engabrevatnet.

\section{Calculated mass balance}

The annual mean specific winter and summer balance is calculated from specific winter and summer net balance curves and the three different altitudinal area distributions. The spatial variations in winter and summer balance are not evaluated, and the balance curves are used as they have been reported to the WGMS. Mean values for 37 years are shown in Table 2. A major conclusion is that the glacier defined by ice flow to the terminus has a smaller winter balance and a more negative summer balance than the other two distributions. The difference in mean glacier-averaged specific winter balance is $-0.12 \mathrm{~m}$ w.e. (from 2.92 to $2.80 \mathrm{~m}$ w.e.), and in mean glacier-averaged specific summer balance is $-0.15 \mathrm{~m}$ w.e. (from -2.32 to $-2.47 \mathrm{~m}$ w.e.). The difference in mean net balance for the period 1970-2006 is $0.27 \mathrm{~m}$ w.e. (between +0.59 and $+0.32 \mathrm{~m}$ w.e.). The cumulative mean specific net balance calculated with the three different area-elevation distributions is shown in Figure 4. The difference in cumulative mean specific mass balance 
between the calculations based on the two distributions defined by Engabrevatnet is small. The mass balance calculated using the area-elevation distribution defined by ice flow to Engabreen is considerably less positive.

The difference in mean specific winter, summer and net mass balance between the two drainage divides defined by ice or water drainage to Engabrevatnet is $<0.05 \mathrm{~m}$ w.e. The difference between calculated mean specific mass balance based on water discharge to Engabrevatnet and ice discharge to the tongue of Engabreen is larger. The maximum difference between mean specific winter and summer balance calculated for a single year is $-0.26 \mathrm{mw}$.e. in 1989 and -0.27 mw.e. in 1990, respectively, while the maximum difference in net balance is $-0.40 \mathrm{~m}$ w.e. in 1989 and 1990. The difference in cumulative net balance for the period 1970-2006 is $-10 \mathrm{~m}$ w.e., which is almost half of the calculated mass surplus in this period (Fig. 4).

\section{DISCUSSION}

\section{Hydrological vs glaciological glacier}

We have shown that the way the drainage divide is defined can have a significant effect on the calculated specific mass balance of a glacier. For Engabreen there are substantial parts of the glacier where meltwater from the ice there drains to Engabrevatnet, but where the ice does not flow and contribute to the tongue of Engabreen. Three main areas of Engabreen are identified here: one on the plateau where the glaciological boundary or ice-flow perimeter can be defined only by studying ice flow and may vary temporally; one small outlet of Svartisen that is adjacent to Engabreen but distinct from it; and an area above a cliff where there is only limited ice avalanching down onto the main glacier body.

When the glacier is redefined according to a glaciological instead of hydrological definition, not only is the area changed substantially, but also the altitudinal area distribution. The 'glaciological' glacier has a smaller range in elevation, the altitudinal interval containing the greatest area of the glacier is lower (instead of 1300-1400 ma.s.l. containing the greatest proportion at $25 \%$, the elevation bin 1200-1300 ma.s.l. contains the greatest proportion at $26 \%$ ) and the glacier generally has a lower mean elevation. This has important implications, such as in modelling glacier response to climate change, especially for a maritime glacier such as Engabreen that is sensitive to small changes in temperature.

In this study, the drainage divides are drawn manually from interpolated contour lines. The interpolations are thus somewhat subjective. However, the varying shape of the glacier surface on the plateau, and uncertainty and errors in the bed and surface topography DEMs, mean that searching for the 'correct' divide is probably futile. For Engabreen, the differences in area because of these factors are insignificant compared with the difference in area due to choice of drainage divide.

\section{Influence of front position variations}

The influence of front position variations on mass-balance results was compared with the influence of different choice of drainage divides. Changes in front position are reported to the WGMS every year, and changes in front position or glacier length are often the parameter modelled when studying glacier changes.
The 2006 summer balance volume below 500 ma.s.l. was calculated for the tongue as mapped in 1968 and in 2001. The area was $0.13 \mathrm{~km}^{2}$ larger in 2001 than in 1968, and the glacier was $110 \mathrm{~m}$ more advanced in 2001 than in 1968. The summer balance volumes were calculated from the specific summer balance curve (2006) and areaelevation distributions from 1968 and 2001. The difference in calculated specific summer mass balance based on hydrological drainage divide to a slightly smaller and steeper tongue in 1968 was $\pm 0.02 \mathrm{mw}$.e. The difference between the reported specific summer balance based on hydrological drainage divide and the specific summer balance based on the 'ice drainage to the glacier tongue' divide is $-0.20 \mathrm{~m}$ w.e. This shows that at Engabreen the influence on the mass balance from moderate front position variations is insignificant compared with the effects of the choice of drainage divides.

\section{CONCLUSIONS}

For plateau glaciers and ice caps, the spatial difference between the ice-flow perimeter and the hydrological divide can be significant. It is important that divides are defined according to the assignment. When mass-balance and glacier length changes are analyzed, the ice drainage to the glacier tongue must be used, whereas studies of mass balance and run-off must be based on water-drainage divides. The example given here for Engabreen shows three ways in which different parts of a glacier may 'belong' to that glacier for hydrological purposes but not for ice-flow purposes. On the plateau area of western Svartisen, ice flow is slow and sub-parallel to the boundary between two outlet glaciers. The ice here was previously thought to flow towards Engabreen tongue, but precise stake position measurements reveal that it actually flows toward Storglombreen. A small separate glacier tongue (Litlebreen) terminates $>1 \mathrm{~km}$ above the main glacier tongue of Engabreen. Water flow from both has the same eventual destination but not the ice. Finally, ice on a steep slope above the main glacier tongue contributes meltwater to Engabreen that flows underneath the tongue, but the ice rarely falls onto the tongue. Similar circumstances to these three examples are regularly found on other glaciers.

A large proportion of the mass-balance glaciers in Norway are outlets from ice caps. Another example where the difference between area draining ice to the tongue and area draining water to a lake or gauging station is significant is Nigardsbreen, one of the major outlet glaciers from Jostedalsbreen ice cap, the largest ice mass in mainland Europe. At Nigardsbreen the difference in area is probably around $15 \%$. At Langfjordjøkelen in Finnmark, the northernmost glacier included in the mass-balance programme, there are probably discrepancies between hydrological and glaciological drainage divides, too. This issue is significant in regions where only a portion of a glacier body is monitored, such as Svalbard, Iceland, Arctic Canada and Patagonia. It is also relevant for valley and cirque glaciers where parts of the glacier do not contribute glacier ice to the main terminus, as is the case, for example, at Storbreen in Norway and Vernagtferner in Austria. For researchers working on glaciers where this issue is relevant, the most important step is being aware of the problem and using caution and precision in how different parameters are defined. Measurements of subglacial topography are essential in defining the 
hydrological boundary for the glacier. To define the ice-flow perimeter, measurements of ice motion are essential. It should always be made clear whether the glacier boundary defined is the hydrological boundary or the ice-flow perimeter.

\section{ACKNOWLEDGEMENTS}

We are grateful to R. Engeset for initiating and supporting this work, which is the first step to homogenize and improve the quality and homogenization of NVE's mass-balance series. Many present and former colleagues at NVE have contributed to the mass-balance fieldwork at Engabreen. Reviews by P. Jansson and R. Pettersson improved the paper. The mass-balance measurements at Engabreen are financed by Statkraft Energi AS.

\section{REFERENCES}

Andreassen, L.M., H. Elvehøy and B. Kjøllmoen. 2002. Using aerial photography to study glacier changes in Norway. Ann. Glaciol., 34, 343-348.

Andreassen, L.M., H. Elvehøy, B. Kjøllmoen, R.V. Engeset and N. Haakensen. 2005. Glacier mass-balance and length variation in Norway. Ann. Glaciol., 42, 317-325.

Dyurgerov, M.B. and C.L. Carter. 2004. Observational evidence of increases in freshwater inflow to the Arctic Ocean. Arct. Antarct. Alp. Res., 36(1), 117-122.

Engeset, R.V. and 6 others. 2000. Modelling of historic variations and future scenarios of the mass balance of Svartisen ice cap, northern Norway. Ann. Glaciol., 31, 97-103.

Geist, T., H. Elvehøy, M. Jackson and J. Stötter. 2005. Investigations on intra-annual elevation changes using multi-temporal airborne laser scanning data: case study Engabreen, Norway. Ann. Glaciol., 42, 195-201.

Jackson, M., I.A. Brown and H. Elvehøy. 2005. Velocity measurements on Engabreen, Norway. Ann. Glaciol., 42, 29-34.

Kennett, M. 1990. Kartlegging av istykkelse og feltavgrensning pä Blämannsisen. NVE Rapp. 8-1990.
Kennett, M., T. Laumann and C. Lund. 1993. Helicopter-borne radio-echo sounding of Svartisen, Norway. Ann. Glaciol., 17, 23-26.

Kennett, M., C. Rolstad, H. Elvehøy and E. Ruud. 1997. Calculation of drainage divides beneath the Svartisen ice-cap using GIS hydrologic tools. Nor. Geogr. Tidsskr., 51(1), 23-28.

Kjøllmoen, B., ed. 2008. Glaciological investigations in Norway 2007. NVE Rapp. 3-2008.

Lemke, P. and 10 others. 2007. Observations: changes in snow, ice and frozen ground. In Solomon, S. and 7 others, eds. Climate change 2007: the physical science basis. Contribution of Working Group I to the Fourth Assessment Report of the Intergovernmental Panel on Climate Change. Cambridge, etc., Cambridge University Press, 337-383.

Oerlemans, J. and 8 others. 2005. Estimating the contribution of Arctic glaciers to sea-level change in the next 100 years. Ann. Glaciol., 42, 230-236.

Østrem, G. and M. Brugman. 1991. Glacier mass-balance measurements. A manual for field and office work. Saskatoon, Sask., Environment Canada. National Hydrology Research Institute. (NHRI Science Report 4.)

Raper, S.C.B. and R.J. Braithwaite. 2006. Low sea level rise projections from mountain glaciers and icecaps under global warming. Nature, 439(7074), 311-313.

Rasmussen, L.A. and H. Conway. 2005. Influence of upper-air conditions on glaciers in Scandinavia. Ann. Glaciol., 42, 402-408.

Sætrang, A.C. 1988. Kartlegging av istykkelse på Vestre Svartisen 1986. NVE Hydrol. Avd. Oppdragsrapp. 3-88.

Schuler, T.V. and 6 others. 2005. Distributed mass-balance and climate sensitivity modelling of Engabreen, Norway. Ann. Glaciol., 42, 395-401.

Tvede, A., ed. 1971. Glasiologiske undersøkelser i Norge i 1970. NVE Hydrol. Avd. Rapp. 2-71.

World Glacier Monitoring Service (WGMS). 2007. Glacier Mass Balance Bulletin No. 9 (2004-2005). ed. Haeberli, W. R. Frauenfelder, M. Hoelzle and M. Zemp. ICSU(FAGS)/IUGG (IACS)/UNEP/UNESCO/WMO, World Glacier Monitoring Service, Zürich.

Zuo, Z. and J. Oerlemans. 1997. Contribution of glacier melt to sealevel rise since AD 1865: a regionally differentiated calculation. Climate Dyn., 13(12), 835-845. 